\title{
EPISTEMIC DEIXIS IN KALAPALO
}

\author{
Ellen B. Basso
}

\begin{abstract}
:
Speakers of Kalapalo, a Southern Carib language spoken in central Brazil, use a complex set of grammatical particles to reference epistemic judgments. Using data from narratives, hereditary leader's ritual communication, ritual songs, conversations, and didactic speech, I use deictic and stance concepts to understand the semantics of this system. A focus on discursive practice illustrates how various intersubjective stance processes are foregrounded by epistemic marking. The paper concludes with discussion of issues requiring further research.
\end{abstract}

Keywords: Epistemology; Carib languages; Stance; Deixis.

\section{Epistemic deixis in Kalapalo}

Epistemology is defined in this paper as grammatical means of referencing a speaker's evaluation of information, particularly, the degree of confidence that a speaker has in the veracity of information. In this regard, epistemology can be usefully contrasted with evidentiality, or the marking of sources of evidence (DeHaan 1999; Aikhenvald 2004). Degrees of confidence are usually called "modality", ranging from certainty, through probability, to possibility, then to weak and finally, an absence of knowledge (Lyons 1977). This model of modality suggests that epistemic practice must have at its core a certain background understanding of truth. But because notions of truth are not always abstract, and vary widely in world cultures, the study of both evidentiality and epistemology seems to touch very firmly on what may be a persistent Eurocentric dogma in linguistic research.

While there has been considerable examination and discussion of evidentiality, linguists rarely have considered epistemic systems in comparative perspective. The Carib languages of lowland Amazonia are a fruitful point of departure for discussion of this matter, as they exhibit complex systems of grammatical epistemic marking as well as evidential affixes. In this paper, I describe my understanding of Kalapalo, a Carib language spoken in the Alto Xingu region of the state of Mato Grosso, central Brazil. ${ }^{1}$ Currently there are approximately 500 speakers of this language living in four

1 This paper builds upon, but in some ways deviates from the pioneering studies of Carib languages by Eithne Carlin (2004) and Eithne Carlin and Jacques Arends (2002) on Trio, Desmond Derbyshire (1985, 1999) on Hixkaryana, Sergio Meira on Tiriyo (1999) and above all Berend Hoff (1986, 1990) on Surinam Carib (Kar'ina), and Bruna Franchetto on Kuikuro (1983, 1990, 2000, 2003, nd), all of whom have discussed the problems with understanding evidentiality and epistemic marking in Carib languages 
communities. The languge is closely related to Kuikuro, described by Franchetto (1990, 2003, nd).

This paper is organized into five sections. In Section 1, I consider the problems to be addressed, as well as some theoretical considerations regarding stance and deixis. In Section 2, I discuss Kalapalo epistemic form classes and syntactic relations. I then proceed in Section 3 with an examination of epistemic expletives. This is followed in Section 4 by a comprehensive listing with examples of the epistemic particles in my data. Finally, in section 5, I conclude with some observations of the problems these Kalapalo data raise for our understanding of the contrast between epistemic and evidential marking, and offer some suggestions for further research and comparison.

\section{Introduction: Some theoretical considerations}

Epistemic judgment is essentially a stance procedure, vital during those speechcentered, developmental situations integrated by how people are involved with each other, how they pay attention to one another in a reciprocal way so as to learn something about one another's worlds and the values they share or dispute. Epistemic marking can be understood best as a pragmatic process contributing to the speaking subject's self-awareness as a participant in such contexts.

Kalapalo grammaticalized epistemic markers belong to two different form classes. The first is a subset (the "epistemic" subset) of the larger particle form class, an important word type in the language. Carib linguists have called these "modal" particles or clitics (Carlin 2004; Derbyshire 1999; Franchetto nd; Hoff 1986; Meira 1999). While epistemic modality in the sense of a "scale" or "grade" does occur in Kalapalo epistemology, there are important non-modal features that emerge as speakers evaluate information, including incredulity (an extreme skepticism or unwillingness to believe), changes in a person's understanding (such as correctives), and counter-factive or contra-spective wishing or hoping.

The second set of epistemic markers is a smaller class of expletives. As I show in the following analysis, these data suggest that for some members of the expletive set and some of the "epistemic" particle class subset, sources of knowledge are referenced at the same time as claims about knowledge are being evaluated by speakers. These sources of knowledge are related semantically to those specified by Aikhenvald (a summary is found in Aikhenvald 2004: 63) but are organized rather differently and do not correspond to any of Aikhenvald's evidential system types.

To complicate matters, in Kalapalo (as in other Carib languages), there are also evidential affixes ${ }^{2}$ These mark evidence as having been heard or experienced personally. There are "hearsay" evidentials in very specific senses, as they are restricted to various kinds of "traditional" and "inherited" knowledge developed by the speaker, particularly in narrative and didactic discourse. I give a brief description of these affixes in Part 5, prior to my concluding discussion of the question of evidential-epistemic relations in the language.

2 See Franchetto nd. for a description of Kuikuro evidentiality (the author, including the epistemic marker wãke, calls the entire set "epistemology"). 
I have found it useful when dealing with the semantic complications of the system to think of the Kalapalo speaker's epistemic marking as a practice contributing to a deictic field (Hanks 2005). I follow De Haan's recent discussion of evidentiality as propositional deixis (2001: 29), in and through which what is indexed is the relationship between the speaker and the perception or action being described. This idea also holds for Kalapalo epistemology. As propositional deixis, Kalapalo epistemic markers index the speaker's positioning vis-à-vis some event-object that is also attended to by listener(s) who in some way are interested in (or, have already taken their own epistemic position on) that object. Hence, through epistemic deixis, a somewhat different and more complex kind of relation necessarily occurs than in evidential marking. This is because the evaluative dimension of epistemic deixis involves an a priori intersubjective relation, during which the participants are connected to each other through how they are formulating their positions regarding the object(s) under description. Moreover, participants not only consider one another's sources of knowledge regarding the objects per se (as in evidentiality) but also formulate responses to one another's epistemic stances- each other's speculations, conclusions, assertions, wishes or regrets. Hence, this positioning vis-à-vis objects, although propositional, need not be considered in terms of propositional "truth" or "falsity". Kalapalo epistemology is as oriented towards what might be called "social" or "revealed" truth as to objective features of objects. This kind of revealed attitude towards some object appears in epistemically marked conclusions and responses. Such validation and verification responses (or their negative formulations; Basso 1986) foreground the specific interactive relations under epistemic construction. In short, the use of epistemic markings in Kalapalo is embedded in complex interactive, dialogic phenomena. This allows for multiple semantic features to be encoded simultaneously. The issue of whether some semantic feature (source of evidence? evaluation of evidence?) is "primary" and others "secondary" or "extended" is thus avoided.

Semantic features are foregrounded in the context of participant frameworks, what people are doing with each other besides talking. Interactive processes are crucial sites of evidence for the meaningful use of Kalapalo epistemic markers, which take on the character of relational (not just evaluative) features. In Hanks' (1992: 70) words, relational features "are inherently embodied in communicative contexts and cannot be reduced to any set of would-be objective dimensions....". We can understand this by considering the discursive processes as contexts that are often extended over a rather lengthy period of time, during which Kalapalo speakers actually feel the necessity for epistemic figuration.

Using the "stance triangle" model of John Du Bois (2007), we can more clearly locate the way the speaker inserts herself as "evaluator" into the description of the event/object, how this points to the relationship between object (event or thing being evaluated), subject (speaker's own self or those of others), and intersubjectivity (activity of seeking or rejecting a stance position or alignment, involving more than one subject). Sometimes one or two of these are being pointed to, sometimes all three at once. Indeed, Du Bois' notion of the "stance triangle" is particularly important, as I have found that the three components in this triangle - speakers' evaluation of objects, their positionings as subjects, and alignments with other subjects ("intersubjectivity" in Du Bois' system) are present in the semantics of Kalapalo epistemic grammar. Du Bois' (2004: 22ff) technical use of "alignment" to refer to ongoing activity "in which two participants in dialogic interaction...converge to varying degrees" in taking a 
stance, is an important example of a discursive procedure in which the epistemic scale is particularly salient, and actually marked grammatically in Kalapalo.

The interest in stance as a fundamental activity of interactive, thinking-feeling individuals promotes the public and embodied, extended processual focus that is adopted here. In Kalapalo, epistemic dialogues are of particular interest because of the Amazonian "perspectivism" that is so characteristic of people's openness to the otherness of the other in their interpersonal relations, coupled with an awareness of phenomenal transformability. ${ }^{3}$ Eithne Carlin, writing of Trio (and referencing the ethnographic work of Peter Rivière), describes this sense of a transforming world as follows:

“...since the world as we know it is vastly greater for a people such as the Trio since it is a synthesis of the visible and invisible, the real in this world and the 'other' world of spirits and the like, claiming certainty about the state of the (whichever) world can be a hazardous affair. One of the most important elements... is that we are constantly living in a state of flux, few things being constant....the Trio live in a transformational world where nothing is as it appears to be, where appearances are deceptive, and everything can change... For the Trio, egocentric knowledge is about as close as one can come to certainty about a given state of affairs." (Carlin 2004: 299)

Kalapalo people have a great interest in illusionary consciousness and deceptive action (augunda) The multiple varieties of creative deception and transformation (augene) described and commented upon in Kalapalo narratives are frequently apparent to them in their own lives (Basso 1987). Users of the Kalapalo register associated with politeness in family life (ifutisunda ekugu, or the most perfect affinal civility) use a variety of metaphorical and other figures in which inversions and substitutions index respectful devaluation of the speaker's gifts and personal attributes in service to an affine (Basso 2007). And the hereditary leader's ritual communication (anetu itagiñu) is also described as augunda by the leaders themselves, with regard to how they epistemically devalue the work of their ceremonial messengers (Basso 2009). Both are of special interest to understanding overt stance taking. Perspectivism is not only a way of interacting and understanding the otherness of beings in the non-human world, it is closely linked to the Kalapalo ideology of language as enabling human creativity, deception, and transformation - a recognition that these are inseparable from being

3 “Amazonian perspectivism" was first described by Eduardo Viveiros do Castro $(1999,2002)$ as a cosmological deixis in which Amazonian people understand non-human entities to be essentially "human" in their perspectives toward entities and events that seem non-human to the human observer. To take a Kalapalo example, what is animal flesh from a human's perspective (and thus forbidden in the Kalapalo diet) is "fish" (acceptable food) to the jaguar. Hard stones that are impossible for a human to eat are simply toasted corn kernels for the jaguar. While there are multiple examples of this kind of "perspectivism" in Amazonian ethnography, it is important to also consider the understanding of entity transformability that is so much a part of that notion. Thus, as I have written, the appearance of (and sounds emitted by) an entity in question is in part a consequence of the context of interaction (or noninteraction) with an other. Thus a jaguar is a "living thing" in the context of its appearance in the natural environment, emitting calls or interjections (itsu) to other animals, but is human in the context of its interaction with a human being, when it uses human language (as in the narrative of the man who married a Jaguar Woman and lived with his Jaguar in-laws); and it is an itseke, 'powerful being' in the context of its interaction with other like beings in its own etu, 'settlement' where it is constantly transforming itself and others through song spells. Thus the man married to a jaguar was enabled to do so through a kind of hallucinatory experiencing, by means of the otherwise fatal itseke properties of his in-laws - properties they manifested in their own environment. 
human. I agree with Franchetto's (nd: 28). analysis of Kuikuro evidentiality as essentially marking discourse as "not deceptive".

Also vital to our understanding are those contexts in which the civility register is abandoned by speakers - situations of angry, disputatious talk, or lustful forgetfulness. Many such contexts are clearly described in Kalapalo stories about families and the viscissitudes of married life. In this paper, much of my data comes from quoted speech in these and other Kalapalo narratives (akiña), especially quoted conversations which substantially constitutes this discourse type, enabling an interpersonal, processual perspective on language use. While quotations in narrative differ from natural speech, insofar as they do not replicate the more usual overlapping utterances heard in casual talk, they are implicitly metadiscursive models for listeners and are often complemented by narrators' explicit metadiscursive commentary, including specification of the attitudes of the speakers, or translations of obscure metaphoric expressions (as would be heard for example in the affinal civility register; Basso 2009). Consequently, I have gleaned considerable information from Kalapalo narratives on how speakers create epistemic deixis in dialogical stance processes; these data demonstrate the importance in such contexts of co-occurring grammatical features such as person marking, aspect and mood. To emphasize the importance of these features, when I discuss the specific forms in question, I cite conversations (some quoted in narratives) and other kinds of data with as clear a statement of their contexts as possible.

The texts in Appendix A and Appendix B illustrate different kinds of Kalapalo stance processes in narratives. (A) is an example of didactic discourse, while (B) illustrates the kind of argumentative, accusatory speech that not infrequently occurs in the context of a story about marriage.

Complementing quoted conversations in Kalapalo narratives are kwambï ritual songs (see Basso 1985 for a description of this ritual practice). These songs are nests of calumny, utterances claimed by others to have been spoken by the singers (or their ancestors), thrown back at the gossipy women, who allegedly spread them around the community. In this song genre, a third stance process ("anti-gossip") occurs; the speaker in effect denies what he/she has been alleged to have said by making public the calumny that was asserted in private. The goal is to shame the original speaker into a denial, yet the singers never use explicit contradictions or denials themselves; many songs however are ripe with epistemic marking. Finally, other data come from the ritual communications of hereditary leaders, every-day didactic discourse, greetings and conversations, and discussions with young Kalapalo speakers about usage.

\section{Epistemic form classes and syntactic relations}

Kalapalo epistemic markers fall into two closed form classes: A sub-set of the more general particle word class (of which there are 24 epistemic markers (EM)), and expletives (EXP) of which there are five or six with epistemic meanings. Particles usually appear after the first element in a clause; the scope of the particle includes the entire clause. Particles almost never accept any derivational or inflectional suffixes except those having to do with clause chaining (both interclausal reference marking and the related taxis particles which connect one event description to another (4.18.3 is an example). Nor are they marked for aspect/mood, person or number. 'Particle' seems the more appropriate word here because of their grammatical distinctiveness from the forms 
they modify. There is an absence of vowel reduction; excepting the form aka, no epistemic particle is vowel initial. Nonetheless, particles do function syntactically as clitics insofar as they are phonologically bound through stress patterning to the constructions they complement, thereby playing a key role in phonological word construction. A minimal epistemic clause is structured as ADV+ EM or NP+EM. While the EM itself is not a verbal element, it references one anaphorically through the evaluative component, and therefore participates in a minimal clause structure.

I use the term expletive to refer not to taboo or profane utterances but to a class of monosyllabic words that may appear as solitary interjections. These words may also initiate utterances in which finite verb clauses appear. In the latter instance, EXP have clear-cut syntactic relations to those clauses, which usually are also marked with one or more EM. Kalapalo EXP have clear epistemic reference to active thinking/feeling, and some have strongly emotive meanings (referencing different kinds of pain, pleasure, and surprise for example). Others in this class seem to be more like true interjections with non-epistemic affective meaning. Much like particles, the scope of an EXP includes the entire clause; when they occur with EM. the EXP highlights the deictic aspect of a thought process that is involved. Five of the six epistemic expletives (uum, kaa, ah, koh, $m a$; uum-ma is the exception), can also function syntactically as particles, that is, following the clause rather than preceding it, but I do not have examples in which the same morpheme both initiates- as EXP - and follows - as EM - a clause.

Particles in general are an important word class in Kalapalo, from one to three syllables long, that modify members of several other classes (particularly adverbs, but also verbs, nouns, questions, and the proper inclusive copula). Within the general class of particles are four basic "closed" sets, each associated with a semantic field. I call these sets: 1) spatial deixis; 2) taxis; 3) affective (or attitudinal) and 4) epistemic. The first two sets are "neutral" or in Franchetto's (1990) terminology, "descriptive" in mood, while the second two are strongly related to interpersonal activity (including imperative, questioning, and intentional discourse) or what Franchetto calls the "interactive mood", and are thus highly relevant to stance operations. Affective particles may precede or follow EM particles which are generally in second (Wackernagel's) position; members of no more than two different particle sub-classes may follow upon other word classes.

Some examples follow to show the syntactic relations of epistemic expletives (EXP), epistemic particles (EM) and other grammatical features of Kalapalo sentences, especially person prefixes, aspect/mood suffixes, and negation. For the sake of clarity, all EXP and EM forms are in boldface italics. In (1) a speaker uses the EM maki, indexing a kind of correction involving uncertainty about, or denial of validity of a prior statement, now reevaluated as correct. The speaker (who is being quoted by a narrator) realizes there is actually a river in a certain place, something he had been uncertain about earlier. In this example, maki is in second position following the deictic adverb ande ("here/now"), which in turn has scope over the following noun phrase, fanguingalefa (=river-metonymic taxis):

(1) ande maki fanguinga-lefa, Ø- nïg=i-feke.

here/now-EM river-MT, say to-PERF=3-ERG

'Ok, now I see that the river is here after all', he said to (him)'. 
In some complex constructions two different kinds of particles may be used, as for example in (2). In this sentence, a single nominal clause is constructed from a negative adverbialization of the demonstrative igey, which is subsequently nominalized by the locative -no and "unlike" suffix -fini. (Each section of the adverb is bracketed for clarity). The derived adverb includes the EM taka, agreement with some one else's description of their experience; in the nominalization part of the construction the speaker has used the evidential (EV) tifa, a speaker confirming his own first-hand experience. The speaker has returned from a trip to his wife's family. His mother notices that his eyes have turned red, the consequence of his living in a very stuffy, smoke-filled house. The speaker doesn't like the kind of living space he has been made to share with his wife's relatives and wants to create a different sort of house. As he is addressing his own mother, he uses the "exclusive we" pronoun (tisuge) in reference to his affines and himself. The EM taka references his mother's just-stated dismay at seeing his reddened eyes; the EV tifa references the speaker's prior experience. Together, these provide a clue that his own planning will be successful. He thus aligns himself with his mother, and appeals to her for alignment at the same time. (Men often speak this way to their mothers seeking agreement for critical projects).

(2) [afitï taka igey-fuÿ̈-ta] [-yo-fini-tifa] tisuge, afiti. [denial EM DEM-resemble-NEG]-LOC-unlike-EV 1+3, denial.

'I agree we others certainly don't have to live this way in that kind of space'.

(3) is an example of a sentence introduced with a quotation followed by an "I told you so" quotative. The quotation (with finite intransitive verb $k i$ - utter) is included in the scope of the EM taka (asserting 2P experience in which the speaker was involved) which follows the quotative, the substance of the main clause:

(3) $u k^{w}$-ayi-fofo $u$ - $k^{w} i-t a$ taka egey. dual-result-IM 1-utter-CI EM DEM

'Let's wait a while.' You know I said that.'

Example (4) includes both an EM (laka: very weak inference, puzzlement, or a strong inability to understand) and the EXP uum, referencing thought of an imaginative nature (perhaps close to "introspective", in Hoff's terminology; in De Haan's deictic model, the speaker has put himself into the sphere of action):

(4) Uum ayi laka ukuge eley, ukuge.

EXP result EM human being DEM, human being

'I suppose that could have been human, a human being'.

In (5) the EM tiki (speaker denies alignment) modifies a negative adverbial prefix tawhich here has an interjection-like function. The speaker, a notorious warrior, has been accused of coming into a community in order to kill everybody there. Actually he is seeking a wife.

(5) ta tiki uk $k^{w}$-oto eya-li u-feke. NEG-EM dual-parent kill-INT-PI 1-ERG 
'It's not right that (you say) I wanted to kill our parent.'

In (6), taken from an historical narrative, a man reminds his younger brother of an event involving a third relative which took place when the brothers were children. This third person is at the time of the utterance in urgent need during a battle with enemies, and the younger brother has suggested they go and help him. This is how the older brother responds:

(6) [t-iyi-la nika wãke] [ ku-piñano-feke wãke O-think/see- NEG EM EM 1+2-ob- ERG EM

$u k^{w}$-oto i-tïgï-pe Ø-agi-pïgï wãke]

dual-parent 3-head-SAL 3-throw away-PERF EM

'Can it be that you don't remember what happened long ago when our older brother threw away our father's head?'

Several things are going on as the older brother answers. First, he uses the same EM (wãke) in the initial adverbial and subsequent main clauses, and also to mark the A ( $k u$ pinano feke $=1+2$-our older brother-ERG) in the main clause. This repetition is characteristic usage of wãke (see more discussion below). Second, the main clause features an initial EM, nika, appealing to the listener's experience. Third, the entire clause is both epistemological and evidential in character as the initial adverbial ( $-\eta i$ 'see/think/know' - the example is in imperative form) references the boy's own firsthand experience. As the first EM, the scope of nika actually falls over the entire sentence. But so does the repeated use of the second EM, wãke (marking strong confidence in first-hand evidence from the past that no longer exists), which links the involvement phrase of the beginning utterance to the first hand but no longer existing visual evidence in the last clauses. Fourth, the speaker emphasizes the A phrase by leftdisplacing it in the main clause (the structure would normally be OVA). The speaker cannot share his brother's suggestion that they go and help as he has good reason to dislike the other relative. (see Basso 1995 for an extended discussion of quoted conversations in the story of Tamakafi).

My rather long introductions to some of the examples suggests that good understanding of the dialogical context is important. If we can know to what these epistemic utterances are responding, we can see how Kalapalo epistemic markers help a speaker to perform an assessment or evaluation of something that has been referenced previously: Either another speaker's observation, planning, or interpretation, or the speaker's own personal experience (through the evidential -tifa). In other words, a stance alignment is taking place. Of course, Kalapalo stance taking and making is not a simple matter of the speaker using an EM alone. In addition to this grammatical referencing of one speaker's attitude towards (another subject's) characterization of some experienced object, stance is also developed by the use of affective particles, evidentials, miratives, and expletives, (as well as prosody, silence, gesture, and other paralinguistic elements of a response). The presence (or absence) of lexemes specific to certain registers not infrequently complement the salient grammaticalized elements. 


\section{Epistemic expletives}

Five expletives (and one compound) have epistemic semantics. A summary may be found in Table 1.

\section{1. uum: Referencing imaginative thought}

This expletive has unusual prosodic features, namely, an initial high tone followed by a descending tone. I have no examples in which uum appears by itself; it is always followed by a concrete reference to what the speaker is thinking about. (See example 2(4) above; an exception is when it appears with - ma, as in 3(6) In this reference, there is usually included one or another correction in the mind of speaker EM.. Examples can be found in the sections describing the particles laka.(4.3), maki (4.14) and muk $\boldsymbol{w}^{\boldsymbol{e}}$ (4.18). .

The Trickster's ear-piercing companion. Kutsafugu, present in the Trickster's home, sees some fruit hanging up in the house and thinks it must be there for him to eat. He says to himself:

uum, ege-mbe-ts-na ñe-ku-tomi

EXP, DEM-SR-EX-INT DE-eat vegetable food-PURP

'I think this was done so it could be eaten'.

\section{2. kaa: Frustrative (often used in mourning)}

This expletive may be used as a particle as well. It is heard when a person returns home announcing the death or transformation of another person somewhere far from home, calling out to the rest of the group:

kaa, kaa, afitï afitï afitïekugu $u k^{w}$-an-ïy-go-lefa

EXP, EXP, denial, denial, denial completely 1+2-EQ-POT-PL-MT

'Why? Why", No, no, no longer will we be together.'

\section{3. koh: No knowledge}

This expletive can stand alone as a response to a question. It is often followed by a clarification of why the speaker says she "doesn't know". These utterances may include EM's (but apparently more usually lexical items elaborate the lack of knowledge ${ }^{4}$.

\footnotetext{
${ }^{4}$ Examples of the first instance include 1) $\boldsymbol{k o h}$, kuge ite, - $\boldsymbol{n}$ apa $-f a=l e=g e y$
}

EX, human feces-EM-R-different-DEM ("I don't know, but it seems to be human shit to me".), with 4.6 yapa because the speaker hadn't observed the source of the objects he is speaking about personally but it is pretty obvious what he is seeing;.and 2), a response with ma, "uncertainty", uwa-koh figi ma; how-EM do EM ("How did it go? (was done).

In the second instance, examples of lexemes include inkomugu ('not known who'); (-fïï 'resembles'), and the curse or "avoidance of responsibility" locution: la-gele...itsa-ni "like thatforever...3-EX-FUT ('So this person will remain (the way they are now)'.) 


\section{4. ah: Indexing strong assertion, and the speaker's own memory}

This expletive is followed by a full description of what the speaker is asserting. The example is a line that begins a first-hand narrative about a mishap (line 10, Appendix A):

ah, utelu segey tafina-i, tafina- $i$,

EXP, 2-go-PI DEM alligator-CL, alligator-CL

'Let me tell you, I went around like you as an alligator, as an alligator.'

There are numerous examples in which $\boldsymbol{a h}$ introduces an utterance in which EM's appear (see examples of $\boldsymbol{a h}$ with the particles tiki 4.13(2); maki 4.14(2); makina 15(2) $\boldsymbol{m u k}^{\boldsymbol{w}} \boldsymbol{e} 4.18$ (3); kalaka 4.21 (3); All these are strong assertive forms, either in the context of a negative response to another's assertion, or corrections in the mind of the speaker. The seemingly anomalous use of $\boldsymbol{a h}$ with the contra-spective $\boldsymbol{m} \boldsymbol{u} \boldsymbol{k}^{\boldsymbol{w}} \boldsymbol{e}$ can be understood with regard to the context. The speaker is asserting a strong wish through a series of semantically inverted metaphors characteristic of the affinal civility register.

\section{5. ma: A marker of uncertainty, this form is typically found with questions}

In the following example, a rhetorical $(\mathrm{y} / \mathrm{n})$ question is used by the speaker, who is criticizing her daughter's husband for having taken a younger sister out of her puberty seclusion basket, suspended from the roof of their house.

ma, tï-tomi $\quad n$ =igey $\quad$ e-fisï-feke e-ikene i-tïtsine=tïfigï

(shock), RQ-PURP OPP=DEM 2-ybr-ERG 2-younger sister 3-lower down=EQPERF

tï-tomi, tï-tomi.

RQ- PURP, RQ- PURP

'Oh no! Why did your younger brother have to lower your younger sister down, why, why?'

\section{6. uum-ma}

In addition, this co-joined expletive pair appears to reference uncertainty of understanding (while observing some surprising or unusual situation). This is usually a straightforward interjection, sometimes followed by the -ikugu ('intensive') clitic.

\begin{tabular}{|l|l|l|}
\hline 1. uum & $\begin{array}{l}\text { Consciousness of thinking self; } \\
\text { self in description of action } \\
\text { (=imaginative) }\end{array}$ & \\
\hline 2. kaa & $\begin{array}{l}\text { Consciousness of self as unable } \\
\text { to act to change; self is in } \\
\text { description on potential moods } \\
\text { (=frustrative) of action }\end{array}$ & \\
\hline
\end{tabular}




\begin{tabular}{|l|l|l|}
\hline $3 . \boldsymbol{k o h}$ & $\begin{array}{l}\text { Consciousness of world outside } \\
\text { self; self not in description } \\
\text { (=unknowing) }\end{array}$ & Denials, negatives \\
\hline $4 . \boldsymbol{a} \boldsymbol{h}$ & $\begin{array}{l}\text { Consciousness of world outside } \\
\text { self; self not in description } \\
\text { (=assertive) }\end{array}$ & Indicative mood; demonstratives \\
\hline $5 . \boldsymbol{m a}$ & $\begin{array}{l}\text { Consciousness of world outside } \\
\text { self; self not in description } \\
\text { (=uncertain) }\end{array}$ & Questions \\
\hline 6. $\boldsymbol{u} \boldsymbol{u m}-\boldsymbol{m a}$ & $\begin{array}{l}\text { Uncertainty of understanding in } \\
\text { context of attempt to try to } \\
\text { understand }\end{array}$ & \\
\hline
\end{tabular}

Table 1 Kalapalo Epistemic Expletives

\section{Epistemic particles}

In what follows, I delineate semantic parameters of the 24 members of the Kalapalo epistemic particle sub-class (see Table 2). A number of these parameters seem to closely match those specified by B.J. Hoff (1986) for Surinam Carib (Kari'na). However, with one exception, I use different language to describe these features, in keeping with my emphasis on deixis, dialogicality and stance process. What Hoff calls "grade" (strongweak-lacking); "speaker's attitude", "appeals on speaker", "change of grade" and "coexistence with supporting or conflicting evidence" are clearly epistemic parameters found in Kalapalo. Their respective Kalapalo equivalents are "grades of confidence" (A, B, F): including strong, probable, possible, uncertain, incredulity, denial, knowledge lacking); "focus on person in subjectivity" (C), "intersubjectivity" (F): "alignments, appeals to another" (D,F); "focus on changing subjectivity; correctives (D)"; and "contra-spective (E)". Hoff's specification of an underlying contrast in the Surinam Carib particle set between the origins of two types of evidence - i.e., "extraspective" (from the "outside world", that is, evidence external to the speaker; public knowledge) and "introspective" (evidence from the "inner world of the speaker"; evidence in the mind of the speaker; private knowledge) - is an evidential feature that in Kalapalo can be better understood with reference to Ferdinand De Haan's deictic perspective, an approach that allows for a semantic description subsuming these evidential and epistemic features.

De Haan (2001) distinguishes between two deictic categories relevant to evidentiality: In the first, the speaker is separated (or separates himself) from the action being described; in the second, the speaker includes himself in the description of the action. In fact, these make sense for Kalapalo, in the context of the stance object being foregrounded in the discourse segment. In my analysis I contrast forms $(\mathbf{1} ; \mathbf{3 - 5})$ where the speaker includes herself in the sphere of action; and others (6-9) where the speaker is separate or excludes herself from the sphere of action. A third deictic field also appears, involving a speaker referencing a second person subject's inclusion in the sphere of action $(2 ; 11)$. As I discuss below, there are other participant frameworks relevant to Kalapalo epistemic markers in which the intersubjective relation is foregrounded and the object-subject relation recedes (sections $\mathbf{D}$ and $\mathbf{F}$, below). Sections A, B, C, and F exhibit epistemic "grades", while $\mathbf{D}$ and $\mathbf{E}$ do not. These "grades" do not represent "degrees of truth", but rather degrees of confidence in judgment. 


\begin{tabular}{|c|c|}
\hline \multirow{2}{*}{\multicolumn{2}{|c|}{$\begin{array}{l}\text { A. Focus on object, speaker is inside the } \\
\text { escription of object or is foregrounded }\end{array}$}} \\
\hline & \\
\hline 1. wãke & Strong, assertive \\
\hline 2. nika & Probable \\
\hline 3. laka & Possible but weak \\
\hline 4. ma & Knowledge lacking, uncertain \\
\hline 5. maya & Incredulity \\
\hline \multicolumn{2}{|c|}{ B. Focus on object, speaker is outside description } \\
\hline \multicolumn{2}{|c|}{ of object or not foregrounded } \\
\hline 6. yapa & Strong, assertive \\
\hline 7. tata & Probable \\
\hline 8. fïna & Possible but weak \\
\hline 9. koh & Knowledge lacking \\
\hline \multicolumn{2}{|l|}{ C.Focus on person in subjectivity } \\
\hline 10. tafa & " $1^{\text {st }}$ person confirmation (self-alignment) \\
\hline 11. kafa & $2^{\text {nd }}$ person asked to align, assertive \\
\hline 12. kato & Speaker aligns with $3^{\text {rd }}$ person, weak \\
\hline 13. tiki & Speaker denies alignment \\
\hline \multicolumn{2}{|c|}{$\begin{array}{l}\text { D. Focus on changing subjectivity; correctives: } \\
\text { speaker volunteers alignment with listener }\end{array}$} \\
\hline 14. maki & $\begin{array}{l}\text { Rejection, doubt becomes agreement with } \\
\text { proposition }\end{array}$ \\
\hline 15. makina & $\begin{array}{l}\text { Rejection/doubt becomes agreement with negative } \\
\text { proposition }\end{array}$ \\
\hline 16. pile & Acceptance becomes rejection of own proposition \\
\hline \multicolumn{2}{|l|}{ E. Contra-spective } \\
\hline 17. kini & Negative (regretful) \\
\hline 18. mukw $^{\mathbf{w}}$ & Positive (hopeful, wishful), in vain \\
\hline \multicolumn{2}{|l|}{$\begin{array}{l}\text { F. Intersubjectivity: Alignments; appeals to } \\
\text { another with grades of confidence }\end{array}$} \\
\hline 19. aka: Existing positive alignment & Asserted, indicative mood \\
\hline 20. taka: Probable alignment & Indicative mood; questions \\
\hline 21. kalaka: Possible alignment & $\begin{array}{l}\text { demonstratives, potential mood, questions; } \\
\text { perfective aspect }\end{array}$ \\
\hline 22. nipa: Possible alignment & Distant past, imperative when in dispute \\
\hline 23. nafa: Alignment weakly possible & Subjunctive, potential moods; distant past \\
\hline 24. nifa: Necessary alignment, must occur & Imperative mood \\
\hline
\end{tabular}

Table 2: Kalapalo Epistemic Particles

A. The speaker is inside the description of the object, or foregrounded. This is accomplished through realis features (demonstratives and or the indicative mood, references to personal experience of motive or cause, as well as to accomplished or completed actions in the past). This set exhibits an epistemic scale of relative grades of understanding.

\section{1. wãke:}

The syntactic, grammatical and semantic functions of wãke are more complex than most of the other epistemic particles. This is an assertive form, with which a speaker bears witness to evidence from the past that no longer exists. Wãke does not necessarily mark 
first-hand evidence, however, but strong and justifiable conviction. For example, it is frequently used in anetu tagiñu, 'hereditary leaders' talk', a style of ritual communication where the speaker references knowledge directly passed down from other leaders. (see further discussion in Basso 1987, 2009; Franchetto nd). Considering the syntactic functions of wãke, in all examples the particle (like other EM) always modifies the first clause. However, in many especially strong assertions (as in contexts of anger, shock or disappointment) wãke appears at the end of each clause. In this regard, the syntactic functions of such repeated scoping seem to also suggest that wãke must have an important affective function. (In the following and all subsequent examples, the name of the speaker or singer is given at the beginning. Readers may turn to the speakers identification key at the end of this paper for gender, relative age and status identification.)

(1)Kudyu: A woman accuses her husband of killing her mother; this example includes the mirative -seku, the EM yapa ( strong probability) and the EM wãke.

ege-seku yapa wãke $u k^{w}$ - oto e-ni wãke tis-iña, wege wãke. you-MIR EM EM dual-parent kill-NEM 1+3-BEN you EM 'I was shocked to realize you, the killer of our parent, preyed on us, that it was you.'

(2) Apihu: A warrior tells his cousin (a lone survivor), that he plans to avenge the dead:

ege-tomi-dye-fa wãke u-te-lï wãke, op-iñi-ko-i u-itsa-ni

you-PURP-SA-R EM 1-go-PI EM, avenge-N-PL-IR 1-EX-FUT 1-

u-ki-lï wãke, ki-ga-tofo-i wãke e-feke.

utter-PI EM , utter-INT-used for-CI EM 2-ERG

'I wanted to go do that so I would be able to avenge you all, (following)

the vow I made to you.'

(3) Kambe: Someone tries to discover the identity of a person in disguise:

uwa-ma wãke efinano i-ñigï wãke, uwa i-ñali.

Q-EM EM older bro. happen to-PERF EM, Q happen to-PI

'What became of his older brother? What happened to him?'

(4) The leader Kambe tells about the ceremonial actions of his ancestors; in this example the evidential feature is highlighted by the appearance of wãke in sentence final position and prosodic emphasis; the epistemic feature is complemented by the initial assertive EXP ah. (Kambe: anetu itagiñu, 'leader's talk' (1979)).

ah figu-mbï-ki-ge-tu-al=igey wãke

EXP grandchild-former-INST-again-BEN-TAXIS=DEM EM

"Believe me, as I've been told about the grandchildren from the past, so again this same thing (is done) here" 


\section{2. nika:}

The speaker recognizes a strong probability and is seeking confirmation, usually in the form of questions. This is often heard used in mourning when the grieving person wails to the deceased.

(1) The following is a common greeting: The perspectivist understanding makes the appearance of a person somewhat problematic. The person could be, after all, an appartition, a dangerous itseke, 'powerful being' disguised as a loved one.

ande nika wegey.

Here/nowEM you

"It seems as if you're here now.'

(to which the listener answers, using the probability alignment EM taka):

Eh, ande taka uge.

Yes, here/now EM me

“'Yes, as you probably can tell, I'm here now.'

(2) Ausuki: Upon seeing turtle's eggs that are much smaller than people anticipated, someone says:

ul - nika- $f=$ igey

ATREM-C $=D E M$

'I guess this is just how they are'

(3) Tufule: A husband is anxiously looking for his wives and comes to a place where he expects to find them. He politely asks some other women if his wives are there:

ayi nika inde u-oku-yi-ta i-ni-lë e-feke-ne

result EM here 1-liquid food-Vt--CI 3-see-PI 2-ERG-PL

'Perhaps you've seen those who make my food around here.'

\section{3. laka:}

The speaker suspects there is a possibility for understanding, but there is puzzlement in the face of evidence.

(1) Ausuki:

uwa-mbe laka u-mugu i-ñ-ïgï

Q-SR EM 1-son 3 -EX-PERF

'How could this have happened to my son?'

(2). Tufule. A person turned monstrous looks for another victim whom he obsessively calls his "brother-in-law": 
unde laka u-fameti a-Ø-nïgi kaah whereEM 1-bro-in-law EXP-say to-PERF FRUST 'Where in the world is my brother-in-law?'

(3) Tufule: The Trickster tells his friend to get some firewood, but Kutsafugu only sees people. Taugi tells him that what he sees are the trees, and he then expresses wonder at the constant illusions and deceptions that now surround him in adult life (that are characteristic of himself as a trickster, in other words):

igey-a laka u-at-ïfigï, igey-a-gage.

DEM-E EM 1-EQ-PERF, DEM-way-forever

'I don't know why I've become like this, always like this.'

\section{4. $\mathrm{ma}$ :}

Used as a particle, this form references the speaker's uncertainty due to lack of knowledge.

(1). Kambe: A narrator questions how someone in his story could put a large fish inside a small flute:

ta-me-ma kuluta atati tu-inga-li i-feke?:

that-FACS-EM flute inside O-insert-PI 3-ERG;

'How could he have put it inside something like that flute?'

(2). Ugaki: People are looking for a man who might have abducted their relative. The following section of the conversation is between the people being asked about it and the people searching for her:

tï-ma=gey kuge Ø-nïgï-t=i-feke

RQ-EM-DEM person say to-PERF-EV=3-ERG

'Who is that person?, that's what I'm told he asked him'

Koh, inko-mugu-tsï yapa-fa ku-pisua-ndau të-feke ma EM, unknown-who-R EM-CO 1+2-brother-PL who-ERG EM

u-funa-lï-feke

1-search -for-PI-ERG

'Who knows? It seems we don't even know as yet which brother of ours we're looking for'

(3) Tawana: Discussing a story about an abducted woman, the narrator explains to me the Kalapalo didn't want to kill the woman's abductor:

Nalï-tsï $\quad \boldsymbol{m a}$ tu-e-lu Kalapalo-feke

Negative-R EM O-kill-PI Kalapalo-ERG 
'I don't think the Kalapalo would have killed him'.

tï-tomi ma tu-e-lu

RQ-PURP EM O-kill-PI

'What reason was there to kill him?'

\section{5. maya:.}

The speaker, while enunciating a proposition, at the same time denies any possibility of its occurrence; this form is used to express incredulity, often with the rhetorical $(\mathrm{y} / \mathrm{n})$ question prefix tii. ( 'I can't believe you're asking/saying $(X)$ as you and I both well know the answer'.)

(1). Tufule:: The Trickster proposes that he make the same kinds of rare and beautiful things given to his younger brother.

um tï-kïtsi maya t-iyuG-isi Taugi ki-lï

EXP RQ-ugly EM O-make-ADV (name) utter-PI

'Who says this is hard to make?" (="This is easy to make"), Taugi spoke.'

(2). Ageu: leader's talk. A leader's ritual communication is often filled with this kind of ironic statement, a kind of respectful devaluation of the work of his own messengers:

tï-kä̈na-fïï maya Ø-atsaki-lï atehe gele-fa wãke

RQ-D-unlike EM 3-run-PI EQ still-R EM

'Who says they don't still run up to (a settlement) as they did before in the past?(=They do still run...)'

(3). Ugaki: A man's wife finds it hard to believe her husband seduced her younger sister.

Uk $k^{w-i k e n e} i$-fi-dyu-fïi $\quad$ maya e-feke, Ø-nïg=i-feke

Dual-y sister 3-touch-PI-resemble EM 2-ERG, say to-PERF=3-ERG

'I can't believe you actually touched our younger sister', she said to him'.

B: In this set, the focus is upon the object, but the speaker excludes herself from the sphere of the object description, usually drawn as irrealis through unobserved or unobservable 3P motivation or causality, and incompletive aspect. An epistemic scale of grades of understanding is present. 


\section{6. yapa.}

This is a strong, assertive form used where certainty is expressed. Some examples suggest yapa is used by speakers in their narratives as a "hearsay" evidential strategy. (see line 5 Appendix B.)

(1) Ausuki: . The speaker has been asked to identify some excrement:

koh, kuge ite, $\sim-$ napa-fa $=$ le $=$ gey

EX, human feces-EM-CO-MT=DEM

'I don't know, but it seems to be human shit to me'.

(2) Tufule: The Trickster gets fire: He makes a decoy out of the rotten body of a deer to lure the vultures, whose messengers tell them:

anetu otu dye yapa-fa f-eley

leader solid food SA EM-CO C-DEM

'That looks like someone put food for the leader down there.'

(3). Tsanaku:

kohotsi ekugu yapa-fa i-nï-ngo-lefa

late afternoon-perfect EM-CO come back-PERF-PL-MT

koge-fundef-egey undufe $t i-\tilde{n} a-t i-\tilde{n}=\ddot{i} m i$

next day-D C-DEM ceremony O-perform-IR-N-PURP

'Apparently they came back at the very end of the day (because) the following day they would perform in the ceremony'.

\section{7 tata.}

There is some uncertainty, but probability from customary experience exists. The action involved a $3^{\text {rd }}$ person and therefore the speaker could not know for certain that the event took place.

(1). Kudyu:

igifagafiti anetu-gu uүu a-nïgï tata i-feke:

(settlement name) leader-POSS. house EQ-PERF EM 1-ERG:

'Possibly there's a house for the Igifagafiti leader.'

(2) Ugaki: A woman recounts another's actions based on common female experience, but since the event took place in the far distant past, the speaker isn't entirely certain of the accuracy of what she's saying.

lepene atu-ndi-li tata i-feke

then tap-Vt-PIEM 3-ERG

'Then I think she might have tapped on it' 


\section{8. fina .}

There is some evidence but it is weak.

(1) The following is a typical remark after the Trickster does something covertly:

\section{Taugi-fina-mbe}

Taugi - EM-SR

'It might have been Taugi who did that'

(2) Kambe: Grandmother Quail sees that some children have pulled up all her peanuts. -fina appears in this example with the mirative -seku, which in this example has scope over both sentences while -fina has scope over the last sentence only.

tï-seku ma egey u-etigite-gï-ki-ga-tiga.

RQ-MIR uncertainty DEM 1-peanuts-POSS-INST-CI-H

enï oto-ni-nïgï-ko

fina-seku-fa.

do food-non-existent-PERF-PL EM-MIR-CO

'What do I see here? Someone's been messing with my peanuts. Could it be that they're having trouble finding food of their own?'

(3) Taguwaki: The forest monster is frightened by a man who disguises himself as an owl in order to chase him away:

adyafi fina-tsa

(owl) EM-EX

'That must be an adafi I'm seeing ' (this owl is a bad sign to the observer).

\section{9. koh.}

The speaker has no knowledge of what is being described.

(1) Tufule: Taugi teaches women how to use piqui. One of the women asks the Trickster:

ayi fogi kalaka të-iñambe $=$ nïm-ino $\boldsymbol{k o h}$

result respond EM O-drink- Vt-POT EM

'I don't know but could a drink be made out of this sometime?'

(2) Olafu: A husband returns and begins to burn a pile of brush in which, unknowingly, his wife's lover is hiding. When the man runs away to escape the fire, the husband says to his wife: 
ukuge wende e-ki-nu koh-i u-feke

person over there 2-utter-N EM-CL I-ERG

'Why didn't you tell me there was someone over there?'

(3). Tawana: Parents are talking about their daughter, whom they have decided has been abducted by a stranger:

uwa ma uk $k^{w-}$ indisi $i$-tsa.

What EM dual-daughter 3- EX

'How can we know what's happening to our daughter?'

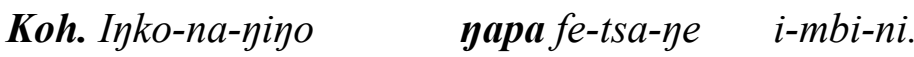

EM. Unknown-DAT-POT EM want-EX-N 3-steal-TN

'Who knows? I don't think we'll ever be able to know who was the person who stole her.'

(4) Ugaki: In her version of the same story, this narrator has the brothers, frustrated in not having found their sister in a nearly settlement, saying the following to one another:

uwa $\boldsymbol{m}=$ igey $u k^{w}$-ijandsu i-ñigï.

What EM=DEM dual-sister 3-EX-PERF

'What could have happened to our sister?

Koh. La-gele-fa $u k^{w}$-inandsu i-tsa-ni

EM. Like that-still-CO dual-sister 3-be-FUT

'Who knows? Our sister will remain like that forever.'

C. In this EM set, the focus of the speaker is on self as actor, and thus the morpheme use is closely correlated with person status. The speaker's affect is also highlighted. Feelings of anger, fear, distress, worry are most usually not mentioned in a narrator's metacommentary unless she wishes to refer to the person's talk, not "inner feelings".

\subsection{0. tafa:}

A first-person form, referencing the speaker's own subjectivity in an assertive way. (tafa is homophonic with the words for "gourd water container"; "duck")

(1) Kudyu: Cuckoo's mother tells him to come home right away if his fiancée decides she doesn't want him after all, and he answers:

sagagey-dye tafa u-en-ïmi-yo ama 3-same-SA EM 1-come back-Vi-POT mother (vocative)

'I will come back, Mother, just as you've described' 
(2) Tufule: The speaker describes how the Trickster copulated before he learned about erections from Lizard:

ule e-tiku-ta $\quad$ tafa $=l e=g e y \quad i$-ñati-gï-ki,

ATR3-copulate-CI EM=MT=DEM 3-finger-POSS-INST

"'Before, they found that he made love to them that way, with his finger,

Taugi-feke tu-fits-au i-ku-ta

(name)-ERG REF-wife-PL 3-copulate-CI

Taugi made love to his wives.'

(3) Tufule: When the door isn't opened for a man who has turned himself into a monster, he says to the people inside:

ande tafa u-a-nïgï

here/now EM 1-EQ-PERF

'I'm here, I'm telling you!' or, 'Can't you hear me? I'm here.'

\subsection{1. kafa:}

This form is used when the speaker addresses a $2 \mathrm{P}$ assertively, seeking alignment but still focused on the 2P subject: "now you (do) know", "do you know?"; there may be worry or concern (as in 4.12), but in the context of the speaker's own conviction perhaps not being shared or understood:

(1) Tufule: A grandfather explains to his young grandson why the latter's brother keeps sending him to dangerous places:

Efiñano-feke kafaf-egey ege ku-ni-ta

older bro-ERG EM C-DEM you envy-Vt-CR

'Now you should know your older brother has been envying you'.

(2) Tufule: Agouti is telling the Trickster Taugi where his wives are hiding:

ayi kafa tu-fu-ti e-feke akugi ki-li

result EM O-know-IR 2-ERG Agouti utter-PI

'Don't you know what's going on?', Agouti asked.'

(3) Ageu: The leader asks one of his fellows to participate in a ceremonial gathering, hoping he will agree but worrying that he will be turned down:

ayi kafa të-ipï-gï e-feke

result EM O-payment-POSS 2-ERG

'Do you know if you can make payment?'

(4). Tawana: A father asks men in a distant community if they know of anyone who might have abducted his daughter: 
ayi kafa inde iñaka-puyu-figï-ko iñandsu-ko-feke kaah, result EM here 3-partner-worthless-PERF-PL sister-PL-ERG-FRUST,

itsa-ta-i-fofo

be-CI-IR-IM

'Do you know of someone here among you without a good partner, who might have wanted this sister of yours?'

\subsection{2. kato:}

The speaker aligns with a $3^{\text {rd }}$ person, and thus the evidence is somewhat weak, puzzling, or even worrisome.

(1) Kudyu: People are trying to kill jaguars. They come to a community to see if some youths can be prepared as warriors:

e-ata-dye kato ku-mugu-ko-feke $u k^{w}$-opi-dyi-ko-ino

2-do-SA EM 1+2-child-PL-ERG dual-avenge-PI-PL-POT

'I'm not sure but if you do (what we've asked) to them, our children just might avenge us.'

(2) from a Kwambï song sung by Kudyu

kuGife-mbe kato ti-ka-gi-ti=feke

witches'dart-SR EM REFL-make-Vt-DES=3-ERG

'I'm worried he wants to make witches' darts'

oi-ñe-mbe kato ti-ka-gi-ti-feke

wind-N-AV EM O-make-Vt-DES=3-ERG

'I'm worried he wants to make those wound-up things.'

(3) Kudyu: Relatives caution their younger nephew about nearby enemies.

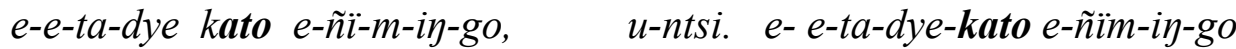

2-kill-SA EM 2-come to-Vi-POT, 1-yrelative. 2-kill-SA-EM 2-come to-POT

'I'm worried they will kill you when you come there my young relative, when you come there.'

\subsection{3. tiki:}

With this form, the speaker denies another's statement; or even the very evidence of her own eyes (with indicatives). This form often has mirative semantics (as examples (1) and (2) below suggest). In fact the form might be derived from the negative mirative clitic -ki (this is a highly polysemous morpheme). 
(1) Mïdaa: A warrior denies he has come to kill people, because he's only there to marry a woman.

ta-tiki e-lï-ko-iña u-e-na-lï

NEG-EM 2-kill-PI-BEN 1-come towards-Vi-PI

'Why should anyone say I've come here to kill you all?'

(2).Kambe: A grandfather sees his two grandsons for the first time. This example is interesting for its miraspective tone:

ah ande-yu tiki u-fi-dyau a-nïgï

EX here/now-DIM EM 1-gchild-PL EQ-PERF

'These little ones here can't be my grandchildren!'

(3) Taguwaki: A woman has been abducted by powerful beings and left in her hammock tied to palms growing in the middle of a lake. When she wakes up, she says:

una tiki egey $u$-e=tïfigï

how EM-DEM 1-come to=EQ-PERF

'How in the world did I get here?'

D. Focus on Changing Subjectivity, Correctives: Forms in this set are used when the speaker's mind has changed in response to another person's correction (or denial) of their original statement.

\subsection{4. maki:}

There is reevaluation from doubt or rejection to acceptance of a proposition. 'I'm right (or wrong) after all'; 'now I realize'

(1) Kudyu: The speaker uses maki with the assertive expletive $\boldsymbol{a h}$ : A person who thought the river was somewhere else sees it and realizes his mistake:

ah, ande maki fanguina-lefa, Ø-nïg=i-feke

EX here/now EM river-MT say to-PERF=1-ERG

'"Well, here's that river at last", he said.'

(2) Madyuta: maki with the the "thinking, imagining, realizing" expletive um. The speaker had rejected the proposition earlier, but has seen for himself how wrong he was to do so:

um, ande maki fotugu-i- isuwï a-tsa-ki-lï

EX here/now EM first-CL 3-father 3-run-Vi-PI

'It does seem to me now that his father was actually the first to run over here, as you said.' 
(3) Ausuki: A man who had been abducted as a child realizes he and his sister are actually members of another group:

afitï maki Tugumay-fïï ku-kuge

denialEM Trumai-unlike 1+2-people)

'I've been wrong, our people aren't Trumai.'

\subsection{5. makina:}

With this form, the speaker moves from rejection to acceptance of a negative proposition: "you're right, it's not", past tense; demonstratives, $3^{\text {rd }}$ person (cf. 4.19, the contra-spective kiyi ("it's too bad...")

(1) Kudyu: A woman tells her lover that her husband has killed her mother. She uses the $\boldsymbol{a} \boldsymbol{h}$ expletive to assert her understanding, which comes from her firsthand knowledge of evidence:

ah, ay-olo-dye-tsï makina $=\boldsymbol{k}=$ igey

EX, exist-ADV-SA-R EM=EM=DEM

'Believe me, I realize now that it's true, this is what happened to her after all as you can see for yourself.'

(2) Tawana: A man uses the polite reference to his parent-in-law:

$u k^{w}$-oto $=$ fo-ko makina egey, $u k^{w}$-oto-fo-ko

dual-parent-COLL-PL EM DEM, dual-parent-COLL-PL

'Now I realize that's not our parent, our parent.'

(3) Tawana:. A woman tells her brothers her abductor was not one of their kind:

ah, ukuge-fïï makina wãke igey wãke,

EX, 1-person-unlike EM EM DEM EM,

u-iki-dyu-lefa $\quad u$-feke tsa=l=feke, $i$-ño-pe-feke.

1-abduct-PI-MT 1-ERG tell-UT=ERG, 3-husband-SAL-ERG

'Believe me, the one who abducted me before wasn't a person like us', she kept telling them about her husband'.

(4) Ohe: 98: 25 (example from a conversation about usage with EB)

afitï makina ege muku-gu i-po-pu-gu-fini maki igey.

Denial EM DEM son-POSS 3-pierced-Vi-POSS-unlikeEM DEM

'No, I realize his son hasn't had his ears pierced as I thought'.

4.16. pile: 
The speaker moves from acceptance to rejection of a proposition; Example 4.15.(3) includes the EM wãke; see also Example 4.1.(1).

(1) Tufule: A young man has agreed to go to dangerous places to get something for his brother (whose wife is his lover), but finally realizes the brother is trying to kill him.

a-faya-y-ofo-i wãke u-a-nïgï pile u-ikuki-ne-ta

2-ear-LOC-USN-CL EM 1-EQ-PERF EM 1-send away-Vt-CI

'I thought that even though I was your co-spouse I could (safely) be sent away'

(2) Tufule: From a story about a female powerful being:

$$
\text { u-i-gu pile-fa a-ta-ni }
$$

1-ornament-POSS-EM-CO EQ-CI

'I mistakenly thought my pubic ornament would be here.'

E. Contra-spective. These morphemes seem to have special relevance for Amazonian "perspectivism" (see my discussion in Section 1). I write 'contra-spective' rather than 'counter-factive' as they are used in response to a stance (overt or not) of an interlocutor. Their use suggests a focus on imaginative subjectivity. Something is observed or stated but the mind of the speaker wishes against all evidence it were otherwise, knowing there is at best a very remote possibility of that happening (though their use often marks the beginning of some wonderful stories!) The two particles (kini and $\boldsymbol{m} \boldsymbol{u} \boldsymbol{k}{ }^{\boldsymbol{w}} \boldsymbol{e}$ ) clearly have both epistemic and affective meanings but their second position location suggests they are properly placed with the other EM. However, there are some exceptions. In 4.18.(3) $\boldsymbol{m} \boldsymbol{u} \boldsymbol{k}^{\boldsymbol{w}} \boldsymbol{e}$ precedes $\boldsymbol{n i f a}$, suggesting the former is serving affective functions. Clearly more examples need to be examined for further clarification of the semantic roles of these particles. In fact, some other particles may share the property of having both EM and AF semantic functions, and others exhibit yet more functions (see my discussion of yapa and wãke).

\subsection{7. kiyi:}

negative contra-spective. The speaker wishes something were not what it actually is (in response to another) ; it can be glossed as "too bad", "regrettably", "were it not so". This EM may be derived from the intransitive verb $\boldsymbol{k i}$-, "utter".

(1) Ugaki. A person from the Fish World decides he's going to put his own new field right next to the small clearing belonging to his wife's sister's husband, who is a poor gardener but ridicules this character for not working. In fact he will make a magically large field with magical crops.

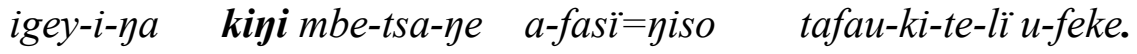
DEM-IR-N EM SR-EX-INT 2-esiz=husband increase size-INST-Vt-PI 1-ERG 
'May he not do the next season what he just did, because I've decided to increase the size of your older sister's husband ('s place).'

In 4.17.(1) kiyi follows the deictic adverb igey-i-ya (=DEM-IR-INT), 'would be like this', yet the scope of the particle in this sentence covers the entire utterance, since the speaker emphasizes the work he will do in the future. The speaker's manner of describing the work itself is a typical self-abnegating affinal posturing that suggests he will actually do something extraordinary. The inter-clausal "same-referent" marker mbe refers to the other man's repeated ridicule (which has just been quoted by the narrator).

(2) Kakaku: A man walking alone suddenly has what appears to be a dangerous apparition. He asks himself:

Uwa =fitsa-tu kiyi f-egey-i

why-apparition Vi EM C-DEM-CL

'Why should it be me who sees this apparition?'

(3) Kambe: A person is going to do something to the otters and asks them not to call out to him even if it hurts badly:

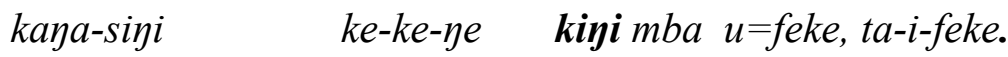

Fish-follow behind NEG-utter-I EM XR 1-ERG, tell-CI-1-ERG

"'Follows the Fish'(name), even if you want to you're not to say that about him to me", he told (them).'

\subsection{8. muk $^{\mathrm{w}} \mathrm{e}$ :}

positive contra-spective; very weak possibility. The speaker "wishes that something were so", appealing to the listener for agreement: (though there is sometimes no direct conversation). "hope you agree", "'I'd like you to do X even if you may not want to) The sense of something being done "in vain" is also sometimes heard, as for example when $\mathbf{m u k}^{\mathbf{w}} \mathbf{e}$ appears repeatedly in the leader's ritual communication (4.18. 3).

(1) Ugaki: Afuseti. Some brothers reach the settlement of a man who has abducted their sister and tell this man they wish to take her back home with them. They are using a very polite register, much like affines would use:

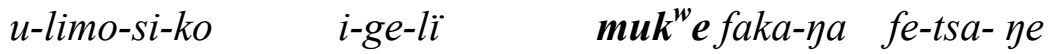

1-child-mother-PL 3-take away-PI EM return-Vi DES-EX-INT

ti-feke igey

1+3- ERG DEM

'You may not want to, but we hope you will agree to let us take our children's mother back with us.'

(2) Ugaki An unmarried woman wishes that a bird she sees were human. 
u-ño-i-ts-ya $\boldsymbol{m u k}^{\boldsymbol{w}} \boldsymbol{e}$ ata-i-ti-tsï-ya egey

1-husband-CL-EX-N EM EQ-IR-DES-R-N DEM

'If only he wanted to make himself different from what he is, he could be a husband for me.'

(3) Kambe: leader's talk

ah fitse-ke mukwe-lefa timbe-ga=ke ei-noku

EXP quickly-I EM-TAXIS arrive-Ci=COM 2P-messenger(s)

'Believe me, I hope they arrived quickly, your messengers'

F. Intersubjectivity: These forms reference various grades of alignments, during which the speaker is including herself and the listener in the sphere of the action.

\subsection{9. aka:}

The speaker declares there is existing, positive alignment between herself and the listener:

(1) Ulutsi: The speaker plans to take revenge after hearing about the death of some comrades:

ande $d y=\boldsymbol{a} \boldsymbol{k a} \quad$ ti-n-en-ïm-ijo

here/now $=\mathrm{XA}=\mathrm{EM}$ REFL-go back-Vi-PPOT

e-fiñano-ko-ake opi-dyi-ko-iña

2-older brother-PL-COM return-PI-PL-BEN

'You're right about that, this time we others will go back in order to return there with you and your older brother.'

(2) Kudyu: A father has been asked to prepare his son for a special role:

afiti-ku aka egitse u-Gi-tu-yu-mbe-su ifo-fïï-egitse

denial-intensive EM MAL 1-dreamVi-N-SR-PEJ image-unlike - MAL

'Unfortunately I have to tell you I never had any useful dreams'.

(3) Tufule: The Dead are invited to return to the living but decline:

ti-tse-l=aka ake-ts-igey-lefa

1+3-go-PI=EM decide-EX-DEM-MT

'And now, as you see, we people must take leave of you.'

\subsection{0. taka}


The speaker suggests the listener will most likely agree with her proposition. In my examples, taka is seen with rhetorical questions, indicative mood, and demonstratives.

(1) Kambe: A man offers his daughters to a potential enemy; this example has $\boldsymbol{m u} \boldsymbol{k}^{\boldsymbol{w}} \boldsymbol{- e}$ and taka. This utterance is typical of the affinal civility register style, in which the speaker devalues a potential gift (Basso 2007). Here, that gift is his daughters:

ayi muk $\boldsymbol{k}^{\boldsymbol{w}}$ etaka tau-go-pïngï fogi-tsïgï u-feke.

result EM EM woman-PAU-DEF find-PERFN 1-ERG

'Though you might not really care, most likely you'll see there are some deficient women I've found.'

(2). Kudyu: The speaker asks a listener to help him remember someone's name:

uwa taka i-ñandsu itite, , Kamisu?

What EM 3-sister name, (name)

'What did I say the sister's name was? Kamisu?'

(3) Nikumalu: The Maned Wolf reminds his abducted wife - now pregnant that he had told her to not walk over his semen; this example illustrates the use of $k i$ - (utter) as a hearsay evidentiality strategy.

inde fe-tsa-ye ke-te-ya u-ki-ta-ti taka e-feke this place want-EX-N NEG-go-INT 1-say-CI-EV EM 2-ERG

'I don't want you to even think about walking around here', I'm pretty sure I heard myself telling you that.' (or, 'I'm pretty sure you heard me keep telling you that")

\subsection{1 kalaka:}

With this form, the speaker suggests a possible alignment with a listener. This form is used with questions, demonstratives, perfective aspect, and potential mood.

(1) Tufule: Women ask the Trickster about how to use a new fruit:

ayi fogi kalaka të-iñambe $=$ nïm-ino

result respond EM O-drink-Vi-POT

'Don't you think a drink could be made out of this sometime?'

(2) Kudyu: Perhaps an example of (lying) though it appears in the context of affinal civility use: The speaker is speaking sadly as if to imply he's been turned down after he offered to go someplace. Actually he wants to take his mother-inlaw someplace where he can kill her:

ayi kalaka $u k^{w}$-oto iךu-kugu-mbo-li result EM dual-parent turn down-completely-Vi-PI 
'Has our parent decided not to go(someplace)?'

(3) Ohe and EB: conversation about usage

ege muku-gu ipo-pïgï kalaka egey-i

this person son-POSS pierce-PERF EM DEM-CL

'Don't you think his son's ears are pierced?'

ah-la-tsï, egey muku-gu i-po-pïgï itsa egey.

EXP-like that-R, that person son-POSS 3- pierce-PERF EX DEM

'Of course that's right, his son's ears have been pierced.'

\subsection{2 nipa:}

In the context of a dispute, this EM marks an offer of, or possibility of alignment on the part of the speaker, who suggests the two could agree with her proposition (if only the listener would think through the proposition carefully enough.) Here the epistemic lexeme $\mathrm{y}$-ke, is used, as in 4.24 (1). Nipa is also seen in examples that reference the distant past, where the speaker can only infer impressions of $3^{\text {rd }}$ persons, as in 4.24 (2).

(1) Kudyu: A warrior is addressing his relative, a person with little experience:

iy-ke elu-mbe-tsï nipa a-piga i-feke-ni

look/think-I kill-SR-R EM 2-club-CI 3-ERG-PL

'Think carefully, don't you realize if (that's what you were to do) they would club us to death?'

(2) Tsanaku: The narrator tells me how beautiful her ancestors were compared with some strangers they had encountered while out fishing. The speaker's use of the adverb ekugu (perfectly, fully, most intensive, completely) and the EM nipa refernces the impressions of others, no longer present:

teh ekugu-mbe nipa u-kuge

EX-perfectly -SR EM 1-people

'My people might have looked really beautiful when that happened (=when other people saw them.)' or 'When they did that they might have seen how beautiful our people were.'

(3) Kambe: The Englishmen. In the context of a dispute about traveling, visitors keep insisting upon going in a certain direction, even though others repeatedly show them the direction to travel so as to avoid enemies:

la nip=e-te-ke, Atatsinu-kai nip=e-te-ke, la.

Over that way EM=2-go-I, name-LOC EM-2-go-I, over that way

'You should go on the Atatsinu (creek), you should go over that way (even though you don't want to).' 


\subsection{3. nafa:}

This morpheme is used when the speaker wishes to appeal to a listener who may have used a nika question, such as 4.2.(3). nafa then confirms 2P experience, as in "as you know, as you have seen”.

(1) Tufule: from a trickster story:

u-ifi-fo-lu nafa e-feke sike-feke-fa e-fife-po-lï

1p-touch-CON-PI EM 2-ERG ant-ERG-CO 2-bite-CON-PI

'You must know if you were to touch me, the ant would bite you'

(2) Kudyu: While introducing the character named Cuckoo, the storyteller confirms that I should already know what he's talking about, as he was keenly aware I had already worked with others identifying Kalapalo bird names:

fitsagu, tu-fu-ti-sï- nafa e-feke

cuckoo, O-know-Vt-PI EM 2-ERG.

'Cuckoo', you must know yourself what that is'.

(3) Ausuki: A man is directing his fellows to a camping place where they can collect turtle's eggs.

enen-oyo mït-oyo-tsï nafa ñetïne mït-oyo-tsï nafa

other side-LOC face-LOC-R EM sand bank face-LOC-R EM

"'Over to the surface on the other side is their customary place," that's what I said, over to the sandbank on the other side.'

\subsection{4. nifa:}

The speaker asserts alignment is necessary, that it must occur. This occurs with the imperative mood and also frequently the speaker uses the epistemic imperative lexeme yke, 'see, think'.

(1) Kudyu: A person tells his mother to think about how he and his wife look:

inke $\quad$ nifa $u k^{w} \ddot{i}$-ij-ke,

see/think-I EM dual-see-I

'Think about how we look to you'.

(2) Nikumalu: The Trickster tells his brother they have to visit their grandmother right away:

$u k^{w}$-atsa-ke nifa ku-nitsu-na, dual-run-I EM 1+2-grandmother-ALL 
"We really should hurry over to that grandmother of ours". Or, "This means we must hurry over to that grandmother of ours'.

\section{Discussion}

The Kalapalo data, when viewed from a deictic perspective, confirms the distinction made by DeHaan and by Aikhenvald between evidentiality and epistemology. As with the related language Kuikuro described by Franchetto, there is at least one grammatical suffix (-tï/ti) marking hearsay evidence, and one particle referencing first-hand experience (-tifa); an apparently moribund "historical knowledge" form is also in my data. ${ }^{5}$ As described at length in this paper, there is also a set of particles that reference epistemic "evaluation" of evidence. An examination of this grammatical set suggests that the contrast proposed by Hoff between "extraspective" and "introspective" can be more accurately treated as an ingredient within a particular Kalapalo deictic field, following De Haan (nd) In the first case, the speaker excludes herself from the sphere of action being described. In the second, the speaker includes herself in the sphere of action being described. However, this contrast does not fully define Kalapalo epistemic deixis.

This Carib deictic dimension does not accord with, and actually foregrounds other features than, those associated with evidentiality in world languages, as listed by Aikhenvald, namely: Visual, non-visual sensory, inference, assumption; hearsay, quotative (2004: 63-4). Nonetheless, as De Haan argues, the evidential features themselves can be closely correlated with one or another deictic process. And yet, these correlations do not yield the same kind of satisfactory understanding as with epistemic

5 What I call the "authoritative hearsay" suffix (-tï/-ti) is an evidential that is commonly used by narrators of mythic stories and in some didactic contexts (if the speaker is an experienced hereditary leader), speech about the anetu itagiñu, 'leader's talk'. This is knowledge that cannot be personally attested to by the speaker, but has been learned from another authority. The value of -tii, often used with the quotative or suffixed to an adverbial introductory narrative segment marker, comes from the speaker being himself indexed as an expert performer of the ancestral knowledge about which he is speaking.

The first hand experience particle - tifa is a first hand experience evidential referencing what the speaker knows either from the past or as planned, potential action that follows from earlier experience. This experience can be idiosyncratic, but it can also be a matter of what the speaker knows about conventional practice. Example (2) shows the use of this morpheme.

In a recent analysis of Kuikuro (nd), Bruna Franchetto describes three other evidentials. The first is $\mathbf{- t s} \boldsymbol{u}$, described as synonymous with $\boldsymbol{t} \boldsymbol{i}$ (nd: 13). In her analysis, - $\boldsymbol{t} \boldsymbol{i}$ is different from - $\boldsymbol{t} \boldsymbol{i}$; I interpret the difference as being caused by vowel elison and treat them as the same morpheme. Franchetto associates yet another pair of suffixes marked for aspect -kilu/-kita (from the intransitive speech act verb ki-, "utter") with historical narratives, that is, marking a speaker's knowledge that has been passed down from one or more narrators with first hand experience, culminating (for the time being) with the present speaker.. I have two similar examples from my own corpus, each used by a single elderly woman in a historical narrative. -kilu/-kita are otherwise absent from all the 14 "historical narratives" told me by eleven different Kalapalo speakers; in some cases these speakers have used the "distanced" hearsay particles described above, treating their "historical" stories in the same way they do "mythic" narratives.

Finally, Franchetto describes a pair of "evidential" suffixes: -tsï and -tsïgï. These are said to be used when a speaker references a recent past experience but the overall frame is mythic. These two forms appear frequently in my data but I interpret them differently. The first is a relativizer, and the second may be a 'personal knowledge/practice' marker. Insofar as the second is not concerned specifically with "sources of evidence", I do not regard it as a type of evidential. 
systems. For example, Aikhenvald distinguishes four types of "two choice" systems. Some of these may correspond to De Haan's deictic types, but for others things aren't as clearly sorted this way. Aikhenvald's (2004: 25) type (a) that distinguishes firsthand (=speaker included in sphere of action) and non-firsthand (=speaker excluded from sphere of action) can be deictically sorted, as can another (b) distinguishing nonfirsthand (as above) versus 'everything else' (unmarked deictically). But when we consider her types (c) reported (or 'hearsay') versus 'everything else'; (d) sensory evidence and reported (or 'hearsay'); and (e) auditory (acquired through hearing) versus 'everything else', the deictic perspective doesn't easily fall into place. In fact, none of these five types corresponds to the Carib epistemic contrast, and only (d) comes close to the evidential system in the Kalapalo/Kuikuro languages.

The several epistemic features shown in Table 2 must be understood within dialogical contexts, that is, as elements within proposals or responses, in which speakers "lead" or "follow" in a particular stance process (Du Bois 2007). For these reasons, and because the Kalapalo system is highly "evaluative", I have used the term "epistemic marking". Nonetheless, we have to accept the fact that (alongside the strictly grammatical evidentials) "evidential" semantics are indeed an important component of the epistemic system. Once again I argue for adoption of De Haan's deictic perspective as a useful analytic tool. Use of this perspective yields several categories (Table 2, A-F) distinguished according to stance relations between speaker, object, and intersubjectivity (Du Bois nd.) Here is where we see how other features of the grammar - co-occurring person marking, aspect/mood suffixing, irrealis formations, and negation - interact significantly with epistemic particles.

Considered further from a deictic perspective, the differences between epistemology and evidentiality have some interesting pragmatic consequences. While it is clear that epistemic marking always involves stance processes, this is not necessarily true of evidential marking (but of course can be true as I would suggest for Kalapalo), if define evidentiality as essentially concerned with marking "sources of evidence". De Haan's suggestion (1999) that evidentiality is derived historically from epistemic modality and his overall discussion of the pragmatic presence of epistemic meanings in evidential usage (and, as has been shown here, evidential strategies - to use Aikhenvald's term - with epistemic markers) is an important topic for further comparative work.

The Kalapalo data suggest two more important grammatical foci for future work on particles/clitics in Carib languages. First, there should be more detailed discussion of the other members of the larger particle class, or what Hoff called the "non-modal particles" (1990), and Carlin (2004) "non-modal clitics". Kalapalo data (not treated in anything like a comprehensive manner here) suggest there are morphosyntactic reasons for distinguishing several subsets of particles, of which the "epistemic" is but one subset. Derbyshire (1999: 53) also suggests subclasses of the important Carib language family particle word class.

A second question concerns the evidential/epistemic semantics of these forms. In Carib languages, there are evidential affixes together with particles/clitics that combine epistemic and evidential semantics. As I have said earlier, some of the semantic features I have specified for Kalapalo accord closely with those described by Hoff for Surinam Carib (Kari'na), and there are similarities to both Trio clitics as described by Carlin, and Hishkaryana particles described by Derbyshire. My differences with Franchetto's analysis of Kuikuro evidentiality are briefly sketched in footnote 5. 
In their analyses, all four linguists clearly combine epistemic semantic features with evidential features. Sometimes this has to do with an approach that is concerned with the pragmatic implicatures of such features (thus, in both Hoff and Carlin, the idea that third person knowledge can never be "truly" known by the speaker influences their understanding of certain evidentials). Derbyshire, writing about Hishkaryana, has used the expression "validation particles" $(1985,1999)$ as well as "evidentiality" (2000). Hoff, writing about Kari'na, keeps to the expression "evidentiality" to describe both a prefix and a suffix, as well as "modal particles", but his discussion must take account of epistemic features that overlap with a distinctly evidential contrast. Franchetto takes the opposite position, calling the Kuikuro forms "epistemology". Carlin uses the overall term "evidential" to describe the semantics of a verbal form, a verbal suffix, and a prefix. Carlin's analysis specifies not only first hand evidential features as being marked but also something like strong conviction or doubt (both epistemological features) inherent in a $3^{\text {rd }}$ person's experience. Carlin's discussion of "evidential modality" includes some forms I would put in my "taxis" particle sub-set. ${ }^{6}$ Obviously I agree with Carlin that there is need for more clarification of the semantics of these forms. It would be useful to correlate verbal person-person configurations with these particle/clitic forms.

Finally, the Kalapalo evidence suggests the relevance of a discourse-focused approach for a more comprehensive understanding of these complex grammatical features. Closer attention needs to be paid to the discursive and especially dialogical contexts in which the forms are used deictically during speech contexts involving relative degrees of a speaker's convergence or divergence with another's stance (Du Bois 2007.:23). We need to understand how these alignments are achieved processually vis-a-vis the speaker's inclusion or exclusion of herself from the sphere of the action being described. An approach that considers deictic functions within a stance model thus seems particularly useful for asking new questions about epistemic marking, requiring careful analysis of extended examples in discourse.

\section{References}

Aikhenvald, Alexandra Y. (2004) Evidentiality. Oxford University Press.

Basso, Ellen B. (1985) A musical view of the universe. Philadelphia: University. of Philadelphia Press.

Basso, Ellen B. (1986) Quoted dialogues in Kalapalo narrative discourse. In Joel Sherzer and Greg Urban (eds.), Native South American discourse. Berlin: Mouton de Gruyer, pp. 119-168.

Basso, Ellen B. (1987) In favor of deceit. A study of tricksters in an Amazonian society. Tucson: University of Arizona Press.

Basso, Ellen B. (1992) Contextualization in Kalapalo narratives. In Alessandro Duranti and Charles Goodwin (eds.), Rethinking Context. Cambridge: Cambridge University Press, pp. 253-269.

\footnotetext{
${ }^{6}$ For example, a Trio clitic (-rëh(ne)) translated "forever, really" is considered an expression of speaker's strong assertive attitude (2004b: 430) and therefore epistemic. I put the Kalapalo cognate (gele), "now as before in the past" into the "taxis" class which marks act-relations.
} 
Basso, Ellen B. (1995) The last cannibals. Austin: University of Texas Press.

Basso, Ellen B. (2007) The Kalapalo affinal civility register. Journal of Linguistic Anthropology 17.2: 161-183.

Basso, Ellen B. (2009) Civility and deception in two Kalapalo ritual styles. In E. Basso and G. Senft (eds.), Ritual Communication. London: Berg.

Carlin, Eithne (2004) A grammar of Trio. Frankfurt am Main: Peter Lang.

Carlin, Eithne, and Jacques Arends (eds.) (2002) Atlas of the languages of Suriname. Leiden: KITLV Press.

De Haan, Ferdinand (1999) Evidentiality and epistemic modality: Setting boundaries. Southwest Journal of Linguistics 18: 83-102.

De Haan, Ferdinand (2001) Encoding speaker perspective: Evidentials. Language Diversity and Linguistic Theories Symposium Proceedings. Linguistische Berichte, Sonderheft 9: 201-16.

Derbyshire, Desmond. (1979) Hixkaryana. Lingua Descriptive Studies 1. Amsterdam: North-Holland.

Derbyshire, Desmond. (1985) Hixkaryana. Dallas: SIL.

Derbyshire, Desmond. (1999) Carib. In Robert M.W. Dixon and Alexandra Y. Aikhenvald (eds.), The Amazonian languages. Cambridge: Cambridge University Press, pp. 23-61.

Du Bois, John W. (2007) Stancetaking in discourse: Subjectivity, evaluation, interaction. In Robert Englebretson (ed.) forthcoming. Stance in Discourse: Subjectivity in interaction. Amsterdam: Benjamins Publishing Company.

Franchetto, Bruna (1983) A fala do chefe: Generos verbais entre os Kuikuru do Alto Xingu. Candernos de Estudos Linguisticos 4: 4-72. Campinas, Brazil.

Franchetto, Bruna (1990) Ergativity and nominativity in Kuikuro and other Carib languages. In Doris L. Payne (ed.), Amazonian Linguistics: Studies in Lowland South American Languages. Austin: University of Texas Press, pp. 407-427.

Franchetto, Bruna (2000) Rencontres rituelles dans le Haut-Xingu: La parole du chef. In Aurore Monod Becquelin and Philippe Erikson (eds.), Les rituelles du dialogue. Nanterre: Societe d'ethnologie, pp. 481510.

Franchetto, Bruna (2003) L'autre du même: Parallêlisme et grammaire dans l'art verbal des récits kuikuro (caribe du Haut Xingu, Brésil). Amerindia 28: 213-247.

Franchetto, Bruna (nd) Les marques de la parole vraie en Kuikuro, langue Caribe du Haut Xingu (Bresil). //www.ailla.utexas.org

Hoff, Berend (1986) Evidentiality in Carib. Lingua 69: 49-103.

Hoff, Berend (1990) The non-modal particles of the Carib language of Surinam and their influence on constituent order. In Doris L. Payne (ed.), Amazonian linguistics: Studies in lowland South American languages. Austin: University of Texas Press, pp. 495-541.

Hanks, William F. (1992) The indexical ground of deictic reference. In Alessandro Duranti and Charles Goodwin (eds.), Rethinking Context. Cambridge: Cambridge University Press, pp. 43-76.

Hanks, William F. (2005) Explorations in the deictic field. Current Anthropology 46.2: 191-220. 
Lyons, John (1971) Semantics. Vol.2. Cambridge: Cambridge Univ. Press.

Meira, Sergio (1999) A Grammar of Tiriyo. Ph.D. dissertation, Rice University.

Viveiros do Castro, Eduardo (1999) Cosmological deixis and Amerindian perspectivism. JRAI (n.s.) 4: 469-488.

Viveiros do Castro, Eduardo (2002) Perspectivismo e multinaturalismo na América indígena. In Eduardo Viveiros de Castro (ed.), A inconstância da alma selvagem (e outros ensaios de antropologia). São Paulo: Cosac and Naify, pp. 345-400.

\section{Appendix A:}

An alligatoring mishap (told by Kakaku at Aifa, 1979) Just as they see the caiman (=alligator) behaving, men roam around the community at night, visiting their lovers. This story illustrates didactic speech; the story-teller within the story isn't really trying to persuade his listener, just reminding him to be careful. Much of this very short story consists in quoted speech: The introductory stated intention of the young man (line 3) sets the ground for the subsequent conversation with his uncle (10 lines of 16).

1. e-tsa-ke-fa

2-listen-I-CO

Listen now.

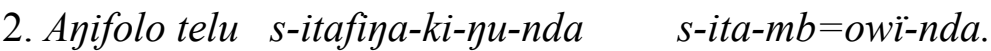

Ancestor go-PI O-alligator-INST-Vi-PI O-stay-Vi=uncle-LOC

An Ancient went alligatoring to where his uncle stayed.
3. U-te-ta-ni
end $=$ ati,
$\emptyset$-nïg $=i$-feke.

1-go-CI-FUT another house-D, say to-PERF-3-ERG

"I'm going to another house", he said to someone.

4. Sin-ïgï s-itafiya-ki-yu-nda fegey.

Come to-Vi-PERF O-alligator-INST-IV-PI DEM

He came there alligatoring

5. Ande yapa ege-funde taina-mbe-fa intse.

Here/now EM DEM-D pile up-SR-CO piqui fruit

They say somewhere around this part of the house over here was a pile of piqui fruit.

6. Intse-gufu-te-pïgï.

Piqui-pile up-Vt-PERF

Piqui piled up.

7.Untsi $\quad$-nïg=i-feke.

My young relative, say to- $\mathrm{PERF}=3-\mathrm{ERG}$

"My young relative", he said to him

8. u-agage $=k e$-tsa-ne ke-iti.

1-like-manner-EX-N NEG-do

"I don't want you to be like me."

9. Uwa-ma awa Ø-nïg=i-feke.

Why-EM uncle say to-PERF=3-ERG

"Why's that, Uncle"? he asked him 
10. Ah u-te-lu segey tafina-i, tafina-i.

EXP 1-go-PI DEM alligator-CL, alligator-CL

"Once I went like you as an alligator, as an alligator."
11. La-ku-dye-ta=ke-tsa-ye
$\varnothing$-nïg $=i$-feke
$u$-te-lu.

Like that-emphatic-SA-CI=manner-EX-INT say to-PERF=3-ERG 1-go-PI

"I had almost reached her," he said,

12. Ande-me yapa-fa tai-ya-ugu-f=u-te-pïgï.

Here/now-FACS EM-CO pile-D-N-CO=1-go to-PERFN

"When I must have gone right towards that pile, probably it was just like this one here,

13. Ule-iminï=gey la-ugu-mbe tu-te uge.

ATR-during=DEM bump into-SR go towards-CI me

And as I kept going, I bumped right into that thing.

14. tik bobobobo,

(sound of the pile being hit) (sound of the fruit falling and rolling around)

Tik bobobobo,

15. ah kugu-fa tai-ya et-ugu-ke-nïgï.

EXP exactly-CO piled up-D 3-DE-fall down-Vi-PERF

which made the whole damn pile fall down
16. bahhaah la-mbe-ku-dya
agïgï imba-ki-lï,
i-fa-ti-lefa

(ideophone) like that-SR-intensive-XA inside wake up-Vi-PI, 3-go out-Vi-MT When that happened all the people inside woke up and he ran outside

\section{Appendix B:}

Atsidyi (Bat) told by Kudyu at Aifa (1979).

Bat convinces his wife that her mother has died after choking on a spiny fish she couldn't resist eating. (In fact he killed her himself and put the fish in her mouth to deceive his wife). Later, Bat (having pretended to be too sick to go to memorialize his mother-in-law), actually does attend (pretending to his wife he is his own cousin). There he participates in the ceremony as the main memorial singer. A series of clues builds uncertainty in his wife, particularly when the mourning song is sung with her mother's name included. The supposed cousin who was singing would have never known her mother's name, only a son-in-law would have (but should never use it as this is an avoidance relation). Bat hurries back to their residence before his wife can return. When she finally appears, Bat (still seeming to feel a bit sick) asks her to delouse him. As she performs this conjugal duty, she discovers a smear of urucu (red paint) that Bat (apparently) forgot to wash off in his haste to cleanse himself of signs of ceremonial participation. The following ensues:

\section{Uum, a Ø-nïg=i-feke}

EXP, EM say to-PERF=1-ERG

"What could this be?", how she began to talk!

2. Poki-ne-nïgïlefa i-feke

Drop-Vt-PERF-MT 1-ERG

As she threw him down.

3. Watsadya, Ø-nïgï, Watsadya. 
(name), say to-PERF, (name)

'Watsadya," she said to him. "Watsadya'

4. Igea-lefa ife-tïfigï i-fitsu-feke.

This way-MT grab-Vt-PERF 1-wife-ERG

As she grapped him like this (by his hair, as the narrator gestures)

5. Watsadya, ta-yo-pe-ma=l=igey a-kai mïyi, ta-yo-pe

(name) O-D-SAL-EM=TAXIS=DEM 2-LOC urucu O-D-SAL

"Watsadya, where did this come from, where did this urucu on you come from?"

6. Puh, ti-kai-dyi-le=gey-lefa.

(sound symbol) REF-LOC-PI-MT=DEM-MT

Puh, he pulled himself up after that.

7. Ifutisu-ki-dyï-f-egey i-feke.

Shame-Vt-PI C-DEM 1-ERG

She had shamed him that way.

8. -figey-funde $\quad i$-fa. ay-apig-ofo-ko-ino

Wood-DEM-LOC wood-R. DT-beat-USN-PL-POT

There was a stick nearby, a stick with which she going to thrash him.

9. ta-yo-pe ige-a e-fitsi-feke ife-tïfigï. ta-yo-pe?

O-D-SAL DEM-N 1-wife-ERG take hold of-Vt-PERF. O-D-SAL

"Where did that come from?" She grabbed it like this (narrator gestures). "Where did that come from?"

10. Unde-ti maya?

Where-O EM

"Even though you really know the answer, you're asking where this came from."

11. Ande. wege-seku yapa wãke $u k^{w}$-oto e-ni wãke tis-iña, wege wãke.

here/now. youMIR EM EM dual-parent kill-N EM 1+3-BEN, you EM

"This here. I can't believe it was you who killed our parent, who preyed on us, that it was you."

12. ta-tiki uk $k^{w}$-oto e-ya-li u-feke.

EXP-EM dual-parent kill-INC-PI 1-ERG

"What do you mean I meant to kill our parent?" (or, "It shouldn't be said I intended to kill our parent ".)

13. ule-pe-ne f-igey a-kai. Ule-pe.

ATR-SAL-N C-DEM 2-LOC. ATR-SAL

"Those parts that came off her is on them. Those parts of her.

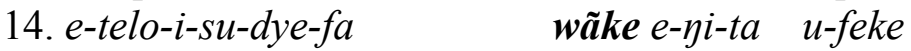

2-different-CL-PEJ-SA-CO EM 2-see-CI 1-ERG

"I realized something about you was different from what you had told me."

15. e-u-fa-ta wãke u-feke, wege-seku-ki wãke

2-know about-CI EM 1-ERG, EM-MIR-MIRN EM

ama-ñu e-ni-wãke, wege-wäke.

mother-END kill-N EM, you -EM

"I should have known it was you, I couldn't believe it when I realized you were dear Mother's killer, you were." 


\section{Abbreviations in interlinear word-by-word glosses:}

(-) separates morphemes; = vowel assimilation; Ø: Unmarked morpheme; , pause ADV: adverbializer; A: anaphoric expansion; ALL: allative; ATR: anaphoric topic referent; B; complement boundary; BEN: benefactive; C: connector; CI continuous aspect, indicative mood; CL: proper inclusion copula; CO: complement marker; COLL: collective; COM: comitative; CONF: conformative taxis; CTR: contradictory taxis; D: spatial deixis; DAT: dative; DEM: demonstrative pronoun; DE: de-ergative; DES: desiderative; DIM: diminuative; DT: different taxis;; E: emphatic (with SAP); END: endearment; EM: epistemic particle; ERG: ergative; EQ: equative copula; EX: existential copula; EXP: expletive; FACS: facsimile; FRUST: frustrative; FUT: future; $\mathrm{H}$ : habitual; I: imperative; IM: immediate taxis; INC inchoative;: IR: irrealis; IV: denominal intransitive verbalizer; INST: instrumental; INT: intentional mood; LOC: locative; MIR: mirative; MIRN: negative mirative; MT: metonymic taxis $\mathrm{N}$ : nominalizer; NEG: negation; O: object/reflexive; PAU: paucal; PEJ: pejorative/ compulsive taxis; PERF: perfective aspect; PI: punctuate aspect, indicative mood; PL: plural; PN: perfective nominalizer; POSS: possessive; POT: punctate aspect, potential mood; PRO: prohibitive prefix; PURP: continuous aspect, purposive mood; Q: question; R: relativizer; REF: reflexive; RQ: rhetorical question; SA: same agent; SAL: salient: SR: same referent; TN: deverbal (transitive) nominalizer; USN: usuative nominalizer; $\mathrm{V}$ : denominal verbalizer; Vi: intransitivizer; Vt: transitivizer;: XA different agent XR: different referent; 1: first person; 2: second person; 1+2: inclusive second person plural; $1+3$ : exclusive second person plural; $3: 3^{\text {rd }}$ person; ybro: younger brother; Z: sister

\section{Practical orthography:}

Vowels: a, as in opera (low front open); e, as in best (middle open; ë, as in "oe" in French coeur (middle closed); i, as in seem (high front open); $\ddot{i}$, as in should (middle open; ə); o, as in old (middle rounded); $\underline{u}$, as in moon (high back rounded). When following the voiceless velar stop $\mathbf{k}$, $\underline{\mathrm{u}}$ is strongly pharyngealized and written as $\mathrm{k}^{\mathrm{w}}$. Stressed vowels are nasalized. Consonants: d, as in English (voiced alveolar stop); dy, somewhat as in the name Nadia, but with more breath (voiced alveo-palatal fricative); $\mathbf{f}$, pronounced while blowing air through loosely opened, untouching lips (voiceless bilbial fricative); g, as in English, but slightly farther back in the mouth (voiced glottal fricative; strongly glottalized $\mathbf{G}$ when preceded by $\mathbf{u}$ ); $\mathbf{h}$, as in English (voiceless glottal fricative); $\mathbf{k}$, as in coffee (voiceless velar stop); $\mathbf{l}$, as in English but tongue is held slightly longer and farther back in the mouth (voiced alveolar lateral); m, as in English (voiced bilabial nasal); $\mathbf{n}$, as in English (voiced alveolar nasal); $\tilde{\mathbf{n}}$ as in Spanish leña; $\mathbf{y}$, similar to sing, but pronounced father back in the mouth (voiced palatal nasal); $\mathbf{p}$, as in English (voiced bilabial stop); $\mathbf{s}$, as in English (voiceless avleopalatal fricative); ts, as in cats (voiceless dental affricate), $\mathbf{t}$, somewhat softer than tooth (voiceless alveolar stop) 


\section{List of speakers and name of the settlements where my work took place.}

key: em=elder male; ef $=$ elder female; $\mathrm{h}=$ hereditary leader; $\mathrm{mf}=$ middle aged female; $\mathrm{mm}=$ middle aged male; $\mathrm{ym}=$ younger male

Ageu: mmh, Aifa Settlement

Ausuki: ymh, Aifa Settlement

Kakaku: em, Aifa Settlement (originally from Dyagami)

Kambe: emh, Aifa Settlement

Kofono: ef, Aifa Settlement

Kudyu: mm, Aifa Settlement (originally from Lahatua)

Madyuta:ymh/mmh, Aifa Settlement

Nikumalu: mm, Aifa Settlement (originally from Wagifiti)

Ofe:ym, Aifa Settlement

Olafu: mm, Aifa Settlement

Tawana: $\mathrm{mm} / \mathrm{em}$, Tayugu Settlement

Tsanaku:efh, Aifa Settlement

Tufule-Muluku: ymh, Aifa Settlement

Ugaki: mf/ef, Aifa Settlement (born in Mehinaku settlement)

Mïdaa-Ulutsi: emh, Aifa Settlement (born in Mehinaku settlement)

\section{Acknowledgments}

I wish to thank the Carib linguists Eithne Carlin, Desmond Derbyshire, Spike Gildea, and Berend Hoff, as well as Ferdinand De Haan, Alexandra Aikhenvald, and R.M.W. Dixon, all of whom have patiently encouraged my work on Kalapalo grammar. Their publications have been indispensable for helping me frame my own questions. Research in the Alto Xingu and work on Kalapalo materials have been generously supported by the National Science Foundation, Wenner-Gren Foundation for Anthropological Research, Inc., John Simon Guggenheim Foundation, the University of Arizona, and the Centre for Research in Linguistic Typology, La Trobe University. I am also very grateful to my colleagues Bruna Franchetto and Carlos Fausto for their kind help and hospitality during a recent period of research in Brazil. Despite our differences in interpretation, Professor Franchetto's writings on Kuikuro have been most important for my understanding of Kalapalo. Above all I express my gratitude to all those Kalapalo of Aifa and Tanguro communities who helped me learn about their language and way of life over many years. 